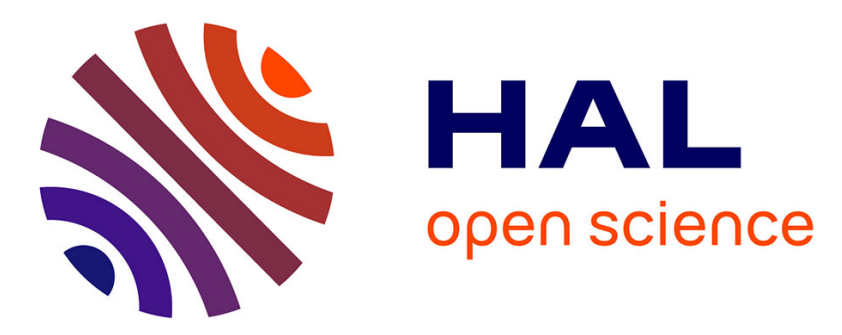

\title{
Isotopic labelling of cultured macroalgae and isolation of 13 C-labelled cell wall polysaccharides for trophic investigations
}

François Thomas, Nolwen Le Duff, Cédric Leroux, Laurence Dartevelle, Pascal Riera

\section{To cite this version:}

François Thomas, Nolwen Le Duff, Cédric Leroux, Laurence Dartevelle, Pascal Riera. Isotopic labelling of cultured macroalgae and isolation of 13 C-labelled cell wall polysaccharides for trophic investigations. Advances in Botanical Research, 2020, 10.1016/bs.abr.2019.11.005 . hal-03035113

\section{HAL Id: hal-03035113 https://hal.science/hal-03035113}

Submitted on 2 Dec 2020

HAL is a multi-disciplinary open access archive for the deposit and dissemination of scientific research documents, whether they are published or not. The documents may come from teaching and research institutions in France or abroad, or from public or private research centers.
L'archive ouverte pluridisciplinaire HAL, est destinée au dépôt et à la diffusion de documents scientifiques de niveau recherche, publiés ou non, émanant des établissements d'enseignement et de recherche français ou étrangers, des laboratoires publics ou privés. 


\section{Isotopic labelling of cultured macroalgae and isolation of ${ }^{13} \mathrm{C}$-labelled cell 2 wall polysaccharides for trophic investigations}

3

4 5

6

7

François THOMAS ${ }^{1, *}$, Nolwen LE DUFF ${ }^{1}$, Cédric LEROUX ${ }^{2}$, Laurence DARTEVELLE ${ }^{1}$, Pascal RIERA $^{3}$

${ }^{1}$ Sorbonne Université, CNRS, Integrative Biology of Marine Models (LBI2M), Station Biologique de Roscoff (SBR), 29680 Roscoff, France

${ }^{2}$ Sorbonne Université, CNRS, FR2424, Station Biologique de Roscoff, 29680 Roscoff, France

${ }^{3}$ Sorbonne Université, CNRS, UMR7144, Station Biologique de Roscoff (SBR), 29680 Roscoff, France

* Correspondence: fthomas@ @b-roscoff.fr

\section{Abstract}

Macroalgae are considered as major primary producers in coastal environments, acting as a global carbon sink. This abundant biomass contains up to $50 \%$ of storage or cell wall polysaccharides, which therefore represent a reservoir of organic matter for potential algal consumers. Tracking of natural isotopic abundance $\left(\delta^{13} \mathrm{C}\right.$ vs. $\left.\delta^{15} \mathrm{~N}\right)$ in macroalgae-colonized habitats such as kelp forests and rocky shores previously evidenced the importance of the algal resource to support local and adjacent trophic webs mostly via the microbial detrital pathway. However, such bulk isotopic measures of natural abundances cannot inform precisely on the microbial actors and processes at play for the degradation of selected algal compounds. To overcome these limitations, we developed a stable isotope labelling procedure for cultures of the brown alga Laminaria digitata and tested its ability to yield labelled polysaccharides. Sporophytes of $L$. digitata were grown in controlled conditions for three months in seawater regularly amended with ${ }^{13} \mathrm{C}$-labelled sodium bicarbonate. Elemental analysis - isotope ratio mass spectrometry of algal specimens showed a significant 
enrichment after 10 days of treatment, reaching a maximum of $\mathrm{At} \%{ }^{13} \mathrm{C}=3.5321 \%$ after 80 days. Sequential polysaccharide extraction from this labelled algal biomass allowed retrieving both alginate and fucose-containing sulphated polysaccharide fractions with high isotopic enrichment $\left(\mathrm{At} \%{ }^{13} \mathrm{C}=3.6279 \%\right.$ and $3.5868 \%$, respectively). This labelling protocol opens the way for future studies combining coastal ecosystems trophic interactions and microbial activities towards macroalgal biomass degradation.

Keywords: (5 to 10$)$

Stable isotope enrichment, alginate, fucose-containing sulphated polysaccharides (FCSPs), macroalgae, degradation, microbial pathway 


\section{Introduction}

The total biomass of macroalgae on Earth is estimated at 280 million tons (Carpenter \& Liss, 2000), covering an area of ca. 3.5 million $\mathrm{km}^{2}$ for a net primary production of up to 1,500 TgC.year ${ }^{-1}$ (Krause-Jensen \& Duarte, 2016). Macroalgae are thus considered as major primary producers in coastal areas, acting as a carbon sink and playing a crucial role in biodiversity and in global carbon flows (Dayton, 1985). The algal chemical composition differs drastically from that of plants and animals. It consists primarily of complex cell wall and storage polysaccharides (more than $50 \%$ of the dry weight), with additional lipids, proteins, pigments and phlorotannins (Deniaud-Bouët et al., 2014). In particular, macroalgae synthesize unique polysaccharides that are absent from other organisms and specific to each phylum, e.g sulfated agars and carrageenans in red algae, alginate and sulfated fucans in brown algae, and ulvan in green algae (Popper et al., 2011). This specific composition of the algal biomass can influence the processes mediating its trophic use.

In marine environments, the availability of organic matter derived from macrophytes for consumers depends on trophic mediation by associated microorganisms (Adin \& Riera, 2003; Crosby, Newell, \& Langdon, 1990; Langdon \& Newell, 1990). Several studies highlighted that bacteria growing on marine phanerogam detritus can facilitate the transfer of carbon to consumers (Benner, Lay, K'nees, \& Hodson, 1988; Tenore, 1977). Laboratory experiments showed that $6-60 \%$ of oyster $\mathrm{C}$ requirements could be met by utilization of detrital complexes comprising senescing tissues and associated bacteria (Crosby et al., 1990; Langdon \& Newell, 1990). Previous studies have pointed out that only about $10 \%$ of the net macroalgal production is consumed directly by grazers (Mann, 1982; Pomeroy, 1980). This low direct grazing pressure on living macroalgal tissues is mostly due to the presence of recalcitrant components including lignocellulosic compounds, and polyphenols like phlorotannins in brown algae (Buchsbaum, Valiela, Swain, Dzierzeski, \& Allen, 1991; Duggins \& Eckman, 
1997). On the other hand, about $90 \%$ of the net macroalgal production enter detritus food chains mostly via microbial degradation (Mann, 1982; Pomeroy, 1980). The pool of detritus derived from macroalgae can be predominant within the total suspended particulate organic matter and represents a readily available food source for many consumers inhabiting kelp forests or nearby areas (Duggins \& Eckman, 1997; Kaehler, Pakhomov, Kalin, \& Davis, 2006). This microbial reinjection of macroalgal biomass into marine food webs plays a quantitative role of prime importance, especially during winter when the phytoplankton production can be very low (Bustamante \& Branch, 1996; Duggins, Simenstad, \& Estes, 1989).

Stable isotopes have been successfully used to trace transformations of organic matter during trophic flows and discriminate among various primary producers as food sources in consumers' diets (Bustamante \& Branch, 1996). Indeed, the isotopic composition of a consumer depends on the diet isotopic composition, and the isotopic fractionation during food processing. Many natural isotopic signatures have been determined for macroalgae during the last decades (Mercado, de los Santos, Lucas Pérez-Lloréns, \& Vergara, 2009; Pinnegar \& Polunin, 2000; Schaal, Riera, \& Leroux, 2010) indicating a wide range of $\delta^{13} \mathrm{C}$ values. In general, average $\delta^{13} \mathrm{C}$ are more ${ }^{13} \mathrm{C}$-enriched in Chlorophyta, intermediate in Phaeophyta and lowest in Rhodophyta (Maberly, Raven, \& Johnston, 1992; Marconi, Giordano, \& Raven, 2011; Mercado et al., 2009). In a kelp forest in western Brittany (France), $\delta{ }^{13} \mathrm{C}$ were more negative for red algae (-38.0 to $-15.5 \%$ ) compared to brown algae (- 24.9 to $-13.5 \%$ ) (Leclerc et al., 2013). Significant differences among species in $\delta{ }^{13} \mathrm{C}$ and/or $\delta{ }^{15} \mathrm{~N}$ were also observed for living macroalgae or strandline algal species (Adin \& Riera, 2003; Dauby, 1989). The $\delta$

${ }^{13} \mathrm{C}$ of marine macroalgae depends largely on their ability to use $\mathrm{HCO}_{3}{ }^{-}$rather than dissolved $\mathrm{CO}_{2}$ as carbon source (reviewed in (Raven et al., 2002)). Macroalgae displaying very low $\delta$ 
${ }^{13} \mathrm{C}$ likely use dissolved $\mathrm{CO}_{2}$ as their main source of inorganic carbon, while $\delta^{13} \mathrm{C}$ close to $10 \%$ corresponds to a preferential fixation of $\mathrm{HCO}_{3}$ - during primary production. Other factors influencing $\delta{ }^{13} \mathrm{C}$ of marine macroalgae include the photosynthesis rates and the molecular composition of algal tissues. These distinct natural isotopic values can be used to assess the contribution of different macroalgal species as food sources for associated consumers. Analyses of stable isotope signatures in kelp forest trophic webs have evidenced the relevance of detrital material as a major food source for the associated benthic communities (Fredriksen, 2003). For example, in a kelp forest dominated by Laminaria digitata, filter-feeders derived $35 \%$ to $50 \%$ of their diet from macroalgae-derived detritus (Schaal et al., 2010). Overall, approaches based on natural stable isotopes confirmed the importance of the microbial detrital pathway to re-inject macroalgal primary production into marine food webs. However, such bulk isotopic measurements of natural abundances cannot inform precisely on the specific contribution of selected algal molecules and on the microbial processes involved in their degradation. A thorough knowledge of these bacterial processes is essential because they directly condition the fate of macroalgal organic matter in marine ecosystems.

A powerful approach to overcome these limitations is to use isotopic enrichment experiments. Experiments based on isotopically labelled biomass have allowed to test specific hypotheses on the fate of distinct food sources and to quantify the trophic fluxes in a variety of marine ecosystems. Stable isotopes enrichments were carried out to selectively label various food sources such as benthic diatoms or bacteria and to determine their relative contribution to the diet of macroinvertebrates (Herman, Middelburg, Widdows, Lucas, \& Heip, 2000; Middelburg et al., 2000). Similarly, the specific uptake of microalgae-derived carbon by the Polychaeta Lanice conchilega or the Echinodermata Echinocardium cordatum was quantified through in situ experiments using ${ }^{13} \mathrm{C}$-labelled diatoms (Kamp \& Witte, 2005). In addition, differential labelling experiments allowed to assess the preferential uptake of ${ }^{15} \mathrm{~N}$ - 
114 labelled bacteria or ${ }^{13} \mathrm{C}$-labelled diatoms by pelagic larvae and foraminiferans (Leroy et al., 115 2012; Moodley et al., 2000; Pascal, Dupuy, Richard, \& Niquil, 2008). So far, stable isotope 116 enrichment studies in marine food webs almost exclusively focused on trophic transfers 117 within planktonic communities or between microorganisms (e.g. microalgae, bacteria) and 118 benthic grazers. By contrast, such approaches are currently lagging behind for macroalgae. 119 Few studies have implemented stable isotope labelling techniques on adult specimens of the red algae Gracilaria spp. and Solieria chordalis to assess their fate in benthic systems (Hardison, Canuel, Anderson, \& Veuger, 2010; Legrand, Martin, Leroux, \& Riera, 2018). However, they used the labelled tissues as bulk biomass and did not investigate the allocation of ${ }^{13} \mathrm{C}$ to specific algal compounds. Some high molecular weight compounds such as cell wall structural polysaccharides can have slower turnover time compared to soluble molecules (e.g. osmolytes, carbon storage compounds) (Brinkhuis, 1977; Macler, 1986) and thus require active growth and longer incubation times to incorporate significant amounts of stable isotopes. Given their high proportion in macroalgal tissues, it appears essential to ensure sufficient labelling of cell wall polysaccharides to fully decipher the fate of macroalgal biomass in marine food webs. In the present study, we developed an adapted protocol to enrich actively growing macroalgae in ${ }^{13} \mathrm{C}$ and obtain isotopically labelled cell wall polysaccharide fractions.

\section{Material and Methods}

\section{Materials}

Natural seawater for algal cultures was collected in opaque containers from the Astan site (GPS coordinates 48 46'40", -256'15") offshore Roscoff (France), filtered on a $100 \mu \mathrm{m}$ 
cartridge and autoclaved before use. ${ }^{13} \mathrm{C}$-enriched sodium bicarbonate $\mathrm{NaH}^{13} \mathrm{CO}_{3}\left(99 \%{ }^{13} \mathrm{C}\right)$ was purchased from Eurisotop (Saarbrücken, Germany). Unless otherwise stated, all other chemicals were from Sigma-Aldrich.

\section{Algal culture procedures}

Laminaria digitata life cycle consists of microscopic haploid gametophyte phase, alternating with macroscopic diploid sporophytes. In this study, all experiments were done on the macroscopic diploid individuals. To obtain young laboratory-grown sporophytes, mature $L$. digitata sporophytes showing sorus reproductive tissues were harvested at the "Roches Duon" site (GPS coordinates 48 43'32", $\left.-3^{\circ} 55^{\prime} 20^{\prime \prime}\right)$. Spores were released from sorus pieces in seawater for $3 \mathrm{~h}$ at $18^{\circ} \mathrm{C}$ with an irradiance of $20 \mu \mathrm{mol} . \mathrm{s}^{-1} \cdot \mathrm{m}^{-2}$ and further kept at $13^{\circ} \mathrm{C}$ at an irradiance of $5 \mu \mathrm{mol} . \mathrm{s}^{-1} . \mathrm{m}^{-2}$ to allow the development of gametophytes and random crosses. The developing young $L$. digitata sporophytes (ca. $5 \mathrm{~mm}$ ) were cultured in flasks containing $10 \mathrm{~L}$ of autoclaved seawater enriched with $1.5 \mathrm{ml}$ of modified Provasoli solution $(92 \mathrm{mM}$ $\mathrm{H}_{3} \mathrm{BO}_{3}, 1.5 \mathrm{mM} \mathrm{FeCl}_{3}, 4.9 \mathrm{mM} \mathrm{MnSO}$, $0.4 \mathrm{mM} \mathrm{ZnSO}$, $0.09 \mathrm{mM} \mathrm{CoSO}$, 27 mM EDTA, 9 $\mathrm{mM}\left(\mathrm{NH}_{4}\right)_{2} \mathrm{Fe}\left(\mathrm{SO}_{4}\right)_{2}, 824.6 \mathrm{mM} \mathrm{NaNO}_{3}, 46.3 \mathrm{mM} \mathrm{C}_{3} \mathrm{H}_{7} \mathrm{Na}_{206} \mathrm{P}, 0.001 \mathrm{mM}$ cyanocobalamine, $0.3 \mathrm{mM}$ thiamine, $0.004 \mathrm{mM}$ biotine, $413 \mathrm{mM}$ Tris) (Starr \& Zeikus, 1993), with continuous bubbling of $0.2 \mu \mathrm{m}$-filtered air in a culture cabinet at $13^{\circ} \mathrm{C}$ illuminated with daylight-type fluorescent lamps at an irradiance of $20 \mu \mathrm{mol} . \mathrm{s}^{-1} \cdot \mathrm{m}^{-2}$ for 12 hours per day. Two separate batches were prepared $\left({ }^{12} \mathrm{C}\right.$-control and ${ }^{13} \mathrm{C}$-enriched) and were regularly amended with $1 \mathrm{~g} . \mathrm{L}^{-}$ ${ }^{1}$ solutions of either $\mathrm{NaHCO}_{3}$ with natural isotopic composition $\left(98.9{ }^{12} \mathrm{C} \%\right.$ ) or labelled $\mathrm{NaHCO}_{3}\left(99{ }^{13} \mathrm{C} \%\right)$ previously sterilized on $0.2 \mu \mathrm{m}$ filters. To favour the growth of larger sporophytes, each batch was subdivided in separate 10L-flasks after 42 and 66 days of cultures. Culture media were renewed biweekly during the first month and weekly afterwards. At each medium renewal, sporophytes were visually examined to eliminate individuals showing signs of necrosis or microbial contamination. All manipulations were performed 
under a sterile laminar flow hood with ethanol-sterilized instruments. At each sampling time $(0,10,18,28,35,52,66,95$ days $)$, three sporophytes were sampled from each batch and frozen at $-20^{\circ} \mathrm{C}$ for isotopic analysis. After 95 days of cultures, the total algal biomass was collected on a strainer and excess water was removed by spinning for $1 \mathrm{~min}$ in a salad tosser. Algae were weighed to estimate the fresh mass, dried at $40^{\circ} \mathrm{C}$ in a ventilated oven for 2 days and stored at room temperature until polysaccharide extraction.

\section{Polysaccharide extraction}

Cell wall polysaccharides were retrieved sequentially using a modified chemical extraction (Deniaud-Bouët et al., 2014; Hogsett \& Quatrano, 1975; Vauchel, Kaas, Arhaliass, Baron, \& Legrand, 2008). Dried algae were pulverized in a MM200 mixer mill (Retsch) at $30 \mathrm{~Hz}$ for 90 seconds. Seven to ten grams of algal powder were homogenized in $300 \mathrm{~mL}$ of $70 \%$ ethanol and filtered on a $100 \mu \mathrm{m}$ nylon mesh placed on a G3 glass filter funnel. The powder was repeatedly rinsed with sequential baths $(250 \mathrm{~mL}, 10 \mathrm{~min}$ each) in $70 \%$ ethanol (3 L total), 80\% ethanol (3 L total), 96\% ethanol (3 L total), methanol / chloroform 50:50 (v/v, 2 L total) and acetone $(0.5 \mathrm{~L}$ total $)$ until colourless and finally dried overnight in a ventilated oven at $40^{\circ} \mathrm{C}$ to yield alcohol-insoluble residues (AIR). AIRs were resuspended in $0.5 \mathrm{~L}$ of $2 \%(\mathrm{w} / \mathrm{v})$ aqueous $\mathrm{CaCl}_{2}$ and mixed for $4 \mathrm{~h}$ at $80^{\circ} \mathrm{C}$, followed by centrifugation for $15 \mathrm{~min}$ at 10000 rpm to separate the calcium-soluble supernatant that contains fucose-containing sulphated polysaccharides (FCSP) from the calcium-insoluble pellet containing alginate. The calciuminsoluble fraction was resuspended in $0.5 \mathrm{~L}$ of $4 \%$ (w/v) aqueous $\mathrm{Na}_{2} \mathrm{CO}_{3}$ for $2 \mathrm{~h}$ at $80^{\circ} \mathrm{C}$ followed by centrifugation for $15 \mathrm{~min}$ at $10000 \mathrm{rpm}$. The supernatant was adjusted to $\mathrm{pH} 2$ with slow addition of $10 \mathrm{~mL} \mathrm{H}_{2} \mathrm{SO}_{4}$ to eliminate carbonates and precipitate alginic acid, which was retrieved by pressing in a $100 \mu \mathrm{m}$ nylon mesh. The precipitate was dissolved in $200 \mathrm{~mL}$ distilled water and neutralized with $\mathrm{NaOH}$. FCSPs and alginate were retrieved from their respective fraction by precipitating with 6 vol. of $96 \%$ ethanol. For recovery, alginate 
was pressed on a $100 \mu \mathrm{m}$ nylon mesh and FCSPs were centrifuged for $20 \mathrm{~min}$ at $9000 \mathrm{rpm}$. Both fractions were lyophilized for long-term storage.

\section{Isotopic analysis}

Triplicate algal samples were dried at $50^{\circ} \mathrm{C}$ for two days in a ventilated oven, pulverized using a mortar and pestle and inserted in tin capsules (1-2 mg per sample). Carbon isotopic ratios were measured on an elemental analyser (Flash EA1112, ThermoScientific) coupled to an isotope ratio mass spectrometer (IRMS Delta plus, ThermoScientific) via a gas interface (Conflo III, ThermoScientific). To measure carbon quantities, expressed in micrograms, a calibration was performed for each run with a certified standard compound (acetanilide, Sylab), a correction for linearity using casein (Sylab) and a two-point linear normalisation (Coplen et al., 2006; Paul, Skrzypek, \& Fórizs, 2007) using the international standards IAEA600 and IAEA-CH6. Data were expressed in the standard $\delta$ notation in \%o according to the following equation:

$\partial{ }^{13} \mathrm{C}=\left(\frac{R_{\text {sample }}-R_{\text {reference }}}{R_{\text {reference }}}\right) \times 1000$, where $\mathrm{R}={ }^{13} \mathrm{C} /{ }^{12} \mathrm{C}$.

These abundances were calculated in relation to the certified reference materials Vienna Pee Dee Belemnite-limestone (V-PDB), with $\mathrm{R}_{\text {reference }}=0.0112372$. The V-PDB was achieved using in-house casein standards, calibrated against IAEA-600 and IAEA-CH6 reference materials. The standard deviation of repeated measurements of $\delta^{13} \mathrm{C}$ of nBS-19 was $0.10 \%$ versus V-PDB.

${ }^{13} \mathrm{C}$ atom percent were calculated as follows:

$\mathrm{At} \%{ }^{13} \mathrm{C}=\frac{R_{\text {sample }}}{R_{\text {sample }}+1} \times 100$ 
${ }^{13} \mathrm{C}$ uptake was calculated in two different ways. Cumulative ${ }^{13} \mathrm{C}$ uptakes $\left(\mathrm{cUp}^{13} \mathrm{C}\right)$ were calculated for each time point $(\mathrm{t})$ by comparing algae from ${ }^{13} \mathrm{C}$-enriched batch to algae from control batch at the same time point, as follows:

$$
c U p^{13} C_{t}=\frac{A t \%^{13} C_{\text {labelled }, t}-A t \%^{13} C_{\text {control }, t}}{100} \times C_{\text {conc }}
$$

213 The first term of the equation represents the ${ }^{13} \mathrm{C}$ atom excess, where $\mathrm{At} \%{ }^{13} \mathrm{C}_{\text {labelled,t }}$ and $214 \mathrm{At} \%{ }^{13} \mathrm{C}_{\text {control,t }}$ are the ${ }^{13} \mathrm{C}$ atom percent values at time $\mathrm{t}$ calculated for algae from batches amended with labelled or natural $\mathrm{NaHCO}_{3}$, respectively. $\mathrm{C}_{\text {conc }}$ is the carbon concentration in dry algal biomass measured by the elemental analyser.

217 In addition, time-resolved ${ }^{13} \mathrm{C}$ uptakes $\left(\mathrm{tUp}{ }^{13} \mathrm{C}\right)$ were calculated for each time point $(\mathrm{t})$ by 218 comparing algae from ${ }^{13} \mathrm{C}$-enriched batch at time $\mathrm{t}$ to algae from the same batch at time $\mathrm{t}-1$ and expressed as daily uptake, as follows:

$$
t U p^{13} C_{t}=\frac{A t \%{ }^{13} C_{\text {labeled }, t}-A t \%{ }^{13} C_{\text {labeled }, t-1}}{100} \times C_{\text {conc }} \times \frac{1}{n_{\text {days }}}
$$

220 The first term of the equation represents the ${ }^{13} \mathrm{C}$ atom excess compared to previous time, 221 where $\mathrm{At} \%{ }^{13} \mathrm{C}_{\text {labeled,t }}$ and $\mathrm{At} \%{ }^{13} \mathrm{C}_{\text {labeled,t-1 }}$ are the ${ }^{13} \mathrm{C}$ atom percent values at time $\mathrm{t}$ and $\mathrm{t}-1$, 222 respectively. $\mathrm{C}_{\text {conc }}$ is the carbon concentration in dry algal biomass measured by the elemental 223 analyser, and $\mathrm{n}_{\text {days }}$ is the number of days between sampling times $\mathrm{t}$ and $\mathrm{t}-1$.

224 The percentage of ${ }^{13} \mathrm{C}$ from sodium bicarbonate incorporated into algal biomass was 225 calculated for the final time point as follows:

$226{ }^{13} \mathrm{C}_{\text {incorp} \%}=\frac{M_{\text {tot }} \times c U p^{13} C_{\text {tfinal }}}{0.99 \times{ }^{13} C_{\text {bicarb }}}$, where $M_{\text {tot }}$ is the total dry algal biomass harvested at the end of 227 the cultivation period, $c \mathrm{Up}^{13} \mathrm{C}_{\mathrm{tfinal}}$ is the cumulative ${ }^{13} \mathrm{C}$ uptake after 95 days of culture, and 
${ }^{13} C_{\text {bicarb }}$ is the total amount of carbon from sodium bicarbonate added during the cultivation period.

\section{Results}

The protocol developed to obtain stable isotope-labelled brown algal biomass is summarized in Figure 1. Labelling of cultured $L$. digitata sporophytes was tested using periodic additions of ${ }^{13} \mathrm{C}$-labelled sodium bicarbonate into seawater, over a 3-months period. In parallel, a control batch of sporophytes from the same fecundation event was prepared with addition of natural abundance sodium bicarbonate.

[Insert Figure 1 here]

In total, each batch was amended with $7.2 \mathrm{~g}$ of sodium bicarbonate, corresponding to $1.1 \mathrm{~g}$ of carbon. Sporophytes grew from $5 \mathrm{~mm}$ to ca. $5-10 \mathrm{~cm}$ in length in 3 months, yielding $123 \mathrm{~g}$ and $95 \mathrm{~g}$ wet biomass in the ${ }^{12} \mathrm{C}$-control and ${ }^{13} \mathrm{C}$-enriched batch, respectively. The water content estimated from the dry biomass was $85 \%$. The ${ }^{13} \mathrm{C}$ isotopic composition and ${ }^{13} \mathrm{C}$ uptake of algal specimens collected at different time points are reported in Figure 2.

[insert Figure 2 here]

At the beginning of the culture, juvenile sporophytes showed a $\delta^{13} \mathrm{C}$ of $-0.50 \pm 2.96 \%$. Typical values obtained from wild adult populations of $L$. digitata in the vicinity of Roscoff range from $\delta^{13} \mathrm{C}=-17 \%$ to $-12 \%$ (Schaal, Riera, \& Leroux, 2009; Schaal et al., 2010). The higher ${ }^{13} \mathrm{C}$-enrichment shown here might reflect differences due to the age of the algal tissues or the specific conditions of cultivation in the laboratory (e.g. amendments with Provasoli solution, air bubbling, etc.). In the control batch, stable isotope compositions remained stable over the 3 months cultivation period (Figure $2 \mathrm{~A}$ ), ranging from $\mathrm{At} \%{ }^{13} \mathrm{C}=1.0855$ to 1.1416, 
with an overall average of $\mathrm{At} \%{ }^{13} \mathrm{C}=1.1116 \pm 0.0201(\mathrm{n}=27)$. By contrast, we observed a rapid enrichment of algal biomass in the ${ }^{13} \mathrm{C}$-enriched batch (Figure 2), already showing At $\%{ }^{13} \mathrm{C}=1.9735 \pm 0.0987$ after 10 days of culture. The ${ }^{13} \mathrm{C}$ content kept increasing until 80 days of culture, when it reached a plateau. The final isotopic composition of labelled algae after 95 days was $\mathrm{At} \%{ }^{13} \mathrm{C}=3.3381 \pm 0.3490 \%$ (Figure $2 \mathrm{~A}$ ). Cumulative ${ }^{13} \mathrm{C}$ uptakes were calculated at each time point (Figure 2B), and showed a final value of $5.59 \mathrm{mg}{ }^{13} \mathrm{C} \cdot \mathrm{g}^{-1} \mathrm{dry}$ algal biomass after 95 days of culture. When extrapolated to the total dry mass of ${ }^{13} \mathrm{C}$ enriched sporophytes harvested at the end of the experiment $(14.14 \mathrm{~g})$, this corresponds to an incorporation of $7.26 \pm 1.76 \%$ of ${ }^{13} \mathrm{C}$ atoms from sodium bicarbonate into algal biomass. Furthermore, we calculated daily ${ }^{13} \mathrm{C}$ uptakes between each sampling time point (Figure $2 \mathrm{~B}$ ). This showed that most of the enrichment occurred during the first 40 days, before the plateau. Daily uptakes became close to zero after 80 days of culture.

A sequential chemical extraction was used to purify cell wall polysaccharides from control and ${ }^{13} \mathrm{C}$-enriched sporophytes (Figure 3) obtained after 95 days.

[insert Figure 3 here]

Alginate was retrieved as the calcium-insoluble fraction of alcohol-insoluble residues whereas the calcium-soluble fraction contained FCSPs, with final yields of ca. $20 \%$ and $7.5 \%$ of the dry weight, respectively (Table 1).

[insert Table 1 here]

Isotopic analysis revealed strongly significant enrichment of polysaccharide fractions extracted from ${ }^{13} \mathrm{C}$-enriched algal biomass compared to controls (Table 2). Alginate and FCSPs showed stable isotope content of $\mathrm{At} \%{ }^{13} \mathrm{C}=3.6279 \pm 0.0009 \%$ and $3.5868 \pm 0.0064$ $\%$, respectively, corresponding to ${ }^{13} \mathrm{C}$ uptakes of $7.02 \pm 0.07$ and $7.07 \pm 0.03 \mathrm{mg}{ }^{13} \mathrm{C} \cdot \mathrm{g}^{-1} \mathrm{dry}$ polysaccharide, respectively. This shows that carbon from sodium bicarbonate was allocated 
275 to cell wall synthesis. In particular, $26 \%$ and $9 \%$ of ${ }^{13} \mathrm{C}$ incorporated into algal biomass was

276 allocated to alginate and FCSPs, respectively.

277 [insert Table 2 here]

\section{Discussion}

Several studies have shown that it is possible to selectively label different food sources and follow their fate within food chains. The ${ }^{13} \mathrm{C}$-enriched labelling can be focused on a source of organic matter considered in its entirety (e.g., whole macroalgae). Experiments based on the ${ }^{13} \mathrm{C}$-labelled red macroalga Gracilaria spp $\left(9 \mathrm{At} \%{ }^{13} \mathrm{C}\right)$ under decomposition in sediments revealed transfers of isotopic label to bacterial biomass through the ${ }^{13} \mathrm{C}$ enrichment of specific bacterial amino acids or fatty acids (Hardison et al., 2010). Recently, a dual stable isotope labelling experiment was performed on adult specimens of the red alga Solieria chordalis using both $\mathrm{H}^{13} \mathrm{CO}_{3}^{-}$and ${ }^{15} \mathrm{NH}_{4}$ additions to investigate the uptake of whole algal tissues by the sea urchin Psammechinus miliaris under different temperature regimes (Legrand et al., 2018). However, stable isotope labelling studies considering macroalgae as a bulk biomass do not inform on (1) the labelling of different molecular fractions of the algae, (2) quantitative transfers of specific algal compounds to different consumers and, (3) the specialization of consumers towards the degradation of specific compounds. When considering the trophic fate of algal constituents, cell wall polysaccharides are of particular interest since they can represent up to $45 \%$ of the dry weight (Mabeau \& Kloareg, 1987), are chemically distinct from those found in other primary producers (Popper et al., 2011), constitute one of the first physical barrier to be attacked by consumers and are generally recognized as more recalcitrant than other small (e.g. simple sugars) or high molecular weight compounds (e.g. proteins). A deeper understanding of the trophic impact of cell wall 
polysaccharides and on the microorganisms specialized in their turnover is therefore crucial to fully understand macroalgal biomass recycling.

In the present study, stable isotope labelling was performed on actively growing juvenile brown algae for 3 months, contrasting with the shorter incubation periods (1-2 weeks) previously used on red algae (Hardison et al., 2010; Legrand et al., 2018). This was required to ensure incorporation of ${ }^{13} \mathrm{C}$-label into cell wall polysaccharides, which can have a long turnover time compared to smaller compounds (Macler, 1986). Indeed, seminal incubation studies of brown algae with ${ }^{14} \mathrm{CO} 2$ or $\mathrm{H}^{14} \mathrm{CO}_{3}{ }^{-}$showed that among sugar constituents, alginate has a slow rate of radioactive carbon incorporation, whereas mannitol is the most rapidly and strongly labelled (Bidwell, 1958; Hellebust \& Haug, 1972; Yamaguchi, Ikawa, \& Nisizawa, 1966). Isotopic ${ }^{13} \mathrm{C}$ enrichments obtained on brown algae in the present study are consistent with levels previously observed on sources characterized by high polysaccharide contents. Recent labelling experiments were performed on fresh leaves of terrestrial source (i.e. alders) with an isotopic ${ }^{13} \mathrm{C}$ enrichment of about $2.5 \mathrm{At} \%{ }^{13} \mathrm{C}$ to assess their assimilation by isopods in groundwater (Francois et al., 2016). A mean ${ }^{15} \mathrm{~N}$ labelling of the seagrass Posidonia oceanica around $4.5 \mathrm{At} \%{ }^{15} \mathrm{~N}$ was also obtained for a quantitative experimental study (Lepoint, Millet, Dauby, Gobert, \& Bouquegneau, 2002). Our detailed time course of ${ }^{13} \mathrm{C}$-incorporation showed that the extent of labelling reached a plateau at the end of the 3-months period and that most of the ${ }^{13} \mathrm{C}$ uptake occurred within 40 days. This suggests that longer incubations in the present experimental setup may not yield a greater incorporation. If even higher ${ }^{13} \mathrm{C}$ enrichments are needed for specific applications, additional ventilation with ${ }^{13} \mathrm{CO}_{2}$ could be tested.

The present results appear very promising for future experimental studies related to the fate and trophic transfers of macroalgal biomass in general and of cell wall polysaccharides in particular. The protocol developed here for the kelp L. digitata can be 
applied to other species of brown, red or green algae for which laboratory cultivation is available. Therefore, the present method complements the toolbox for quantitative trophic ecology approaches to trace ${ }^{13} \mathrm{C}$-labelled macroalgal biomass within complex pelagic or benthic communities of marine ecosystems. Furthermore, this study is to our knowledge the first to report the purification of ${ }^{13} \mathrm{C}$-labelled cell wall polysaccharide fractions containing alginate and FCSPs. Macroalgae are generally considered as a unique pure source in trophic models, although they in fact comprise diverse molecular compounds potentially at the base of different food chains due to their specific utilization by micro- and macro-organisms in aquatic ecosystems. By giving access to specific ${ }^{13} \mathrm{C}$-labelled polysaccharide fractions, the present protocol will help improving the definition of these distinct trophic niches and paves the way for detailed investigations of the diversity and functional processes of uncultured specialized microorganisms responsible for the reinjection of algal polysaccharides into trophic chains via the detrital pathway. To this end, various stable-isotope-enabled microbial ecology techniques are available, such as Stable Isotope Probing (SIP) combined to highthroughput sequencing (Dumont \& Murrell, 2005), Raman single-cell microspectroscopy (Wagner, 2009) or nano-scale chemical imaging by secondary ion mass spectrometry (nanoSIMS) (Musat, Foster, Vagner, Adam, \& Kuypers, 2012). Such studies using ${ }^{13}$ Clabelled polysaccharides as substrates would allow linking specific members of natural microbial communities to their function as degraders of the macroalgal biomass in situ, greatly enhancing our current knowledge on the carbon cycle in marine regions.

\section{Acknowledgements}

F.T. acknowledges support from the Centre National de la Recherche Scientifique (CNRS) with regards to the "ALGOSIP" project and from the French Agence National de la Recherche (ANR) with regard to the "ALGAVOR" project (grant agreement ANR-18-CE02- 
0001-01). All authors are also grateful to ANR for its support with regards to the investment expenditure program IDEALG (grant agreement No. ANR-10-BTBR-04). This work has benefited from the facilities of the Metabomer platform supported by the BiogenouestCorsaire core facility.

\section{References}

Adin, R., \& Riera, P. (2003). Preferential food source utilization among stranded macroalgae by Talitrus saltator (Amphipod, Talitridae): a stable isotopes study in the northern coast of Brittany (France). Estuarine, Coastal and Shelf Science, 56(1), 91-98. https://doi.org/10.1016/S0272-7714(02)00124-5

Benner, R., Lay, J., K’nees, E., \& Hodson, R. E. (1988). Carbon conversion efficiency for bacterial growth on lignocellulose: Implications for detritus-based food webs. Limnology and Oceanography, 33(6, part2), 1514-1526. https://doi.org/10.4319/lo.1988.33.6part2.1514

Bidwell, R. G. S. (1958). Photosynthesis and metabolism of marine algae: II. A survey of rates and products of photosynthesis in $\mathrm{C}^{14} \mathrm{O}_{2}$. Canadian Journal of Botany, 36(3), 337349. https://doi.org/10.1139/b58-029

Brinkhuis, B. H. (1977). Seasonal variations in salt-marsh macroalgae photosynthesis. I. Ascophyllum nodosum ecad scorpioides. Marine Biology, 44(2), 165-175. https://doi.org/10.1007/BF00386956

Buchsbaum, R., Valiela, I., Swain, T., Dzierzeski, M., \& Allen, S. (1991). Available and refractory nitrogen in detritus of coastal vascular plants and macroalgae. Marine Ecology Progress Series, 72(1/2), 131-143. https://doi.org/10.2307/24825436 

derived organic matter on the west coast of South Africa. Journal of Experimental Marine Biology and Ecology, 196, 1-28. https://doi.org/10.1016/0022-0981(95)00093-3

Carpenter, L. J., \& Liss, P. S. (2000). On temperate sources of bromoform and other reactive organic bromine gases. Journal of Geophysical Research, 105(D16), 20539-20547. https://doi.org/10.1029/2000JD900242

Coplen, T. B., Brand, W. A., Gehre, M., Gröning, M., Meijer, H. A. J., Toman, B., \& Verkouteren, R. M. (2006). New Guidelines for $\delta^{13}$ C Measurements. Analytical Chemistry, 78(7), 2439-2441. https://doi.org/10.1021/ac052027c

Crosby, M. P., Newell, R. I. E., \& Langdon, C. J. (1990). Bacterial mediation in the utilization of carbon and nitrogen from detrital complexes by Crassostrea virginica. Limnology and Oceanography, 35(3), 625-639. https://doi.org/10.4319/lo.1990.35.3.0625

Dauby, P. (1989). The stable carbon isotope ratios in benthic food webs of the Gulf of Calvi, Corsica. Continental Shelf Research, 9(2), 181-195.

Dayton, P. K. (1985). Ecology of kelp communities. Annual Review of Ecology and Systematics, 16(1), 215-245. https://doi.org/10.1146/annurev.es.16.110185.001243

Deniaud-Bouët, E., Kervarec, N., Michel, G., Tonon, T., Kloareg, B., \& Hervé, C. (2014). Chemical and enzymatic fractionation of cell walls from Fucales: insights into the structure of the extracellular matrix of brown algae. Annals of Botany, 114(6), 12031216. https://doi.org/10.1093/aob/mcu096

Duggins, D. O., \& Eckman, J. E. (1997). Is kelp detritus a good food for suspension feeders? Effects of kelp species, age and secondary metabolites. Marine Biology, 128(3), 489495. https://doi.org/10.1007/s002270050115 
Duggins, D. O., Simenstad, C. A., \& Estes, J. A. (1989). Magnification of secondary production by kelp detritus in coastal marine ecosystems. Science, 245(4914), 170-173.

Dumont, M. G., \& Murrell, J. C. (2005). Stable isotope probing — linking microbial identity to function. Nature Reviews Microbiology, 3(June), 499-504.

Francois, C. M., Mermillod-Blondin, F., Malard, F., Fourel, F., Lécuyer, C., Douady, C. J., \& Simon, L. (2016). Trophic ecology of groundwater species reveals specialization in a low-productivity environment. Functional Ecology, 30(2), 262-273. https://doi.org/10.1111/1365-2435.12484

Fredriksen, S. (2003). Food web studies in a Norwegian kelp forest based on stable isotope $\left(\delta^{13} \mathrm{C}\right.$ and $\left.\delta^{15} \mathrm{~N}\right)$ analysis. Marine Ecology Progress Series, 260, 71-81. https://doi.org/10.2307/24867089

Hardison, A. K., Canuel, E. A., Anderson, I. C., \& Veuger, B. (2010). Fate of macroalgae in benthic systems: Carbon and nitrogen cycling within the microbial community. Marine Ecology Progress Series, 414, 41-55. https://doi.org/10.3354/meps08720

Hellebust, J. A., \& Haug, A. (1972). Photosynthesis, translocation, and alginic acid synthesis in Laminaria digitata and Laminaria hyperborea. Canadian Journal of Botany, 50(1), 169-176. https://doi.org/10.1139/b72-022

Herman, P. M. J., Middelburg, J. J., Widdows, J., Lucas, C. H., \& Heip, C. H. R. (2000). Stable isotopes as trophic tracers: combining field sampling and manipulative labelling of food resources for macrobenthos. Marine Ecology Progress Series, 204, 79-92. https://doi.org/10.2307/24863624

Hogsett, W. E., \& Quatrano, R. S. (1975). Isolation of polysaccharides sulfated during early embryogenesis in Fucus. Plant Physiology, 55, 25-29. 
Kaehler, S., Pakhomov, E. A., Kalin, R. M., \& Davis, S. (2006). Trophic importance of kelpderived suspended particulate matter in a through-flow sub-Antarctic system. Marine Ecology Progress Series, 316, 17-22. https://doi.org/10.3354/meps316017

Kamp, A., \& Witte, U. (2005). Processing of ${ }^{13}$ C-labelled phytoplankton in a fine-grained sandy-shelf sediment (North Sea): Relative importance of different macrofauna species. Marine Ecology Progress Series, 297, 61-70. https://doi.org/10.3354/meps297061

Krause-Jensen, D., \& Duarte, C. M. (2016). Substantial role of macroalgae in marine carbon sequestration. Nature Geoscience, 9(10), 737-742. https://doi.org/10.1038/ngeo2790

Langdon, C. J., \& Newell, R. I. E. (1990). Utilization of detritus and bacteria as food sources by two bivalve suspension-feeders, the oyster Crassostrea virginica and the mussel Geukensia demissa. Marine Ecology Progress Series. Inter-Research Science Center. https://doi.org/10.2307/24842204

Leclerc, J.-C., Riera, P., Leroux, C., Lévêque, L., Laurans, M., Schaal, G., \& Davoult, D. (2013). Trophic significance of kelps in kelp communities in Brittany (France) inferred from isotopic comparisons. Marine Biology, 160(12), 3249-3258. https://doi.org/10.1007/s00227-013-2306-5

Legrand, E., Martin, S., Leroux, C., \& Riera, P. (2018). Effect of temperature on an algagrazer trophic transfer: A dual stable isotope $\left({ }^{13} \mathrm{C},{ }^{15} \mathrm{~N}\right)$ labeling experiment. Marine Ecology, 39(2), 1-6. https://doi.org/10.1111/maec.12495

Lepoint, G., Millet, S., Dauby, P., Gobert, S., \& Bouquegneau, J. M. (2002). Annual nitrogen budget of the seagrass Posidonia oceanica as determined by in situ uptake experiments. Marine Ecology Progress Series, 237, 87-96. https://doi.org/10.3354/meps237087 
Leroy, F., Riera, P., Jeanthon, C., Edmond, F., Leroux, C., \& Comtet, T. (2012). Importance of bacterivory and preferential selection toward diatoms in larvae of Crepidula fornicata (L.) assessed by a dual stable isotope $\left({ }^{13} \mathrm{C},{ }^{15} \mathrm{~N}\right)$ labeling approach. Journal of Sea Research, 70, 23-31. https://doi.org/10.1016/j.seares.2012.02.006

Mabeau, S., \& Kloareg, B. (1987). Isolation and analysis of the cell walls of brown algae : Fucus spiralis, F. ceranoides, F. vesiculosus, F. serratus, Bifurcaria bifurcata and Laminaria digitata. J. Exp. Bot., 38(194), 1573-1580.

Maberly, S. C., Raven, J. A., \& Johnston, A. M. (1992). Discrimination between ${ }^{12} \mathrm{C}$ and ${ }^{13} \mathrm{C}$ by marine plants. Oecologia, 91(4), 481-492.

Macler, B. A. (1986). Regulation of carbon flow by nitrogen and light in the red alga, Gelidium coulteri. Plant Physiology, 82(1), 136-141. https://doi.org/10.1104/pp.82.1.136

Mann, K. H. (Kenneth H. (1982). Ecology of coastal waters : a systems approach. University of California Press.

Marconi, M., Giordano, M., \& Raven, J. A. (2011). Impact of taxonomy, geography, and depth on $\delta^{13} \mathrm{C}$ and $\delta^{15} \mathrm{~N}$ variation in a large collection of macroalgae. Journal of Phycology, 47(5), 1023-1035. https://doi.org/10.1111/j.1529-8817.2011.01045.x

Mercado, J. M., de los Santos, C. B., Lucas Pérez-Lloréns, J., \& Vergara, J. J. (2009). Carbon isotopic fractionation in macroalgae from Cádiz Bay (Southern Spain): Comparison with other bio-geographic regions. Estuarine, Coastal and Shelf Science, 85(3), 449-458. https://doi.org/10.1016/j.ecss.2009.09.005

Middelburg, J. J., Barranguet, C., Boschker, H. T. S., Herman, P. M. J., Moens, T., \& Heip, C. H. R. (2000). The fate of intertidal microphytobenthos carbon: An in situ ${ }^{13} \mathrm{C}-$ 
labeling study. Limnology and Oceanography, 45(6), 1224-1234. https://doi.org/10.4319/lo.2000.45.6.1224

Moodley, L., Boschker, H. T. S., Middelburg, J. J., Pel, R., Herman, P. M. J., De Deckere, E., \& Heip, C. H. R. (2000). Ecological significance of benthic foraminifera: ${ }^{13} \mathrm{C}$ labelling experiments. Marine Ecology Progress Series, 202, 289-295. https://doi.org/10.3354/meps202289

Musat, N., Foster, R., Vagner, T., Adam, B., \& Kuypers, M. M. M. (2012). Detecting metabolic activities in single cells, with emphasis on nanoSIMS. FEMS Microbiology Reviews, 36(2), 486-511. https://doi.org/10.1111/j.1574-6976.2011.00303.x

Pascal, P.-Y., Dupuy, C., Richard, P., \& Niquil, N. (2008). Bacterivory in the common foraminifer Ammonia tepida: Isotope tracer experiment and the controlling factors. Journal of Experimental Marine Biology and Ecology, 359(1), 55-61. https://doi.org/10.1016/J.JEMBE.2008.02.018

Paul, D., Skrzypek, G., \& Fórizs, I. (2007). Normalization of measured stable isotopic compositions to isotope reference scales - a review. Rapid Communications in Mass Spectrometry, 21, 3006-3014. https://doi.org/10.1002/rcm

Pinnegar, J. K., \& Polunin, N. V. C. (2000). Contributions of stable-isotope data to elucidating food webs of Mediterranean rocky littoral fishes. Oecologia, 122(3), 399409. https://doi.org/10.1007/s004420050046

Pomeroy, L. R. (1980). Detritus and its role as a food source. In R. S. K. Barnes \& K. H. Mann (Eds.), Fundamentals of aquatic ecosystems (pp. 84-102). Blackwell Scientific Publications, Oxford, UK.

Popper, Z. a, Michel, G., Hervé, C., Domozych, D. S., Willats, W. G. T., Tuohy, M. G., ... 
Stengel, D. B. (2011). Evolution and diversity of plant cell walls: from algae to flowering plants. Annual Review of Plant Biology, 62, 567-590. https://doi.org/10.1146/annurev-arplant-042110-103809

Raven, J. A., Johnston, A. M., Kübler, J. E., Korb, R., McInroy, S. G., Handley, L. L., ... Dunton, K. H. (2002). Mechanistic interpretation of carbon isotope discrimination by marine macroalgae and seagrasses. Functional Plant Biology, 29(3), 355-378. https://doi.org/10.1071/PP01201

Schaal, G., Riera, P., \& Leroux, C. (2009). Trophic significance of the kelp Laminaria digitata (Lamour.) for the associated food web: a between-sites comparison. Estuarine, Coastal and Shelf Science, 85(4), 565-572. https://doi.org/10.1016/J.ECSS.2009.09.027

Schaal, G., Riera, P., \& Leroux, C. (2010). Trophic ecology in a Northern Brittany (Batz Island, France) kelp (Laminaria digitata) forest, as investigated through stable isotopes and chemical assays. Journal of Sea Research, 63, 24-35.

Starr, R. C., \& Zeikus, J. A. (1993). UTEX - the culture collection of algae at the University of Texas at Austin. Journal of Phycology, 29(s2), 1-106.

Tenore, K. R. (1977). Growth of Capitella capitata cultured on various levels of detritus derived from different sources. Limnology and Oceanography, 22(5), 936-941.

Vauchel, P., Kaas, R., Arhaliass, A., Baron, R., \& Legrand, J. (2008). A new process for extracting alginates from Laminaria digitata: Reactive extrusion. Food and Bioprocess Technology, 1(3), 297-300. https://doi.org/10.1007/s11947-008-0082-x

Wagner, M. (2009). Single-cell ecophysiology of microbes as revealed by Raman microspectroscopy or secondary ion mass spectrometry imaging. Annual Review of Microbiology, 63, 411-429. https://doi.org/10.1146/annurev.micro.091208.073233 
510 Yamaguchi, T., Ikawa, T., \& Nisizawa, K. (1966). Incorporation of radioactive carbon from

$511 \mathrm{H}^{14} \mathrm{CO}_{3}{ }^{-}$into sugar constituents by a brown alga, Eisenia bicyclis, during photosynthesis

$512 \quad$ and its fate in the dark. Plant and Cell Physiology, 7(2), 217-229.

513 https://doi.org/10.1093/oxfordjournals.pcp.a079175

514

515

516 
Table 1: Yields of cell wall polysaccharide extraction from L. digitata cultured sporophytes

519 from the ${ }^{12} \mathrm{C}$-control and ${ }^{13} \mathrm{C}$-enriched batch. FCSP: fucose-containing sulphated 520 polysaccharides

\begin{tabular}{lcc}
\hline & ${ }^{12}$ C-control & ${ }^{13}$ C-enriched \\
\hline Starting dry biomass $^{1}$ & $10 \mathrm{~g}$ & $7.5 \mathrm{~g}$ \\
Alcohol-insoluble residues $^{\mathrm{a}}$ & $5.73 \mathrm{~g}(57.3 \%)$ & $4.41 \mathrm{~g}(58.8 \%)$ \\
Alginate $^{\mathrm{a}}$ & $1.92 \mathrm{~g}(19.2 \%)$ & $1.57 \mathrm{~g}(20.9 \%)$ \\
FCSP $^{\mathrm{a}}$ & $0.83 \mathrm{~g}(8.3 \%)$ & $0.53 \mathrm{~g}(7.1 \%)$ \\
\hline
\end{tabular}

${ }^{\mathrm{a}}$ Values in brackets are yields based on starting dry biomass

Table 2: Stable isotope ratios of polysaccharide fractions extracted from ${ }^{12} \mathrm{C}$-control and ${ }^{13} \mathrm{C}$ enriched L. digitata sporophytes. Values are mean \pm standard deviation of technical triplicates.

\begin{tabular}{ccc}
\hline \multirow{2}{*}{ Sample } & \multicolumn{2}{c}{$\mathbf{A t \%}^{13} \mathbf{C}$} \\
& Alginate & FCSP \\
\hline${ }^{12}$ C-control & $1.1337 \pm 0.0004$ & $1.1454 \pm 0.0008$ \\
${ }^{13}$ C-enriched & $3.6279 \pm 0.0009$ & $3.5868 \pm 0.0064$ \\
\hline
\end{tabular}

Figure 1: A. Schematic overview of the algal cultivation protocol for stable isotope labelling.

B. Photograph of the experimental setup for cultivation of L. digitata sporophytes.

Figure 2: A. ${ }^{13} \mathrm{C}$ atom percent of algal specimens collected at different time points in the control (blue) and ${ }^{13} \mathrm{C}$-enriched culture batches. Values are mean \pm standard deviation $(\mathrm{n}=3)$. B. Uptake in ${ }^{13} \mathrm{C}$ calculated for algae in the ${ }^{13} \mathrm{C}$-enriched culture batch, calculated either in a 
534 cumulative way compared to algae from control batch (black, left axis) or as a daily uptake 535 calculated for each time point compared to previous time point (white, right axis).

536 Figure 3: Schematic overview of the polysaccharide extraction process. EtOH, ethanol. $537 \mathrm{MeOH}$, methanol. FCSP, fucose-containing sulphated polysaccharides. 